\title{
Analisis dan Perancangan Sistem Informasi E-Klinik Basmallah Pada Masa Pandemi COVID-19
}

\author{
Saleh Yaakub ${ }^{1}$, Hafiz Nugraha ${ }^{2}$, Ilham Pahlevi ${ }^{3}$, Dimas Syaputra ${ }^{4}$ \\ 1,2,3,4 Program Studi Sistem Informasi, Fakultas Sains dan Teknologi, Universitas Muhammadiyah Jambi, Jambi, \\ Indonesia \\ ${ }^{1} \underline{\text { saleh@umjambi.ac.id, }}{ }^{2}$ hafiznugraha@umjambi.ac.id, ${ }^{3}$ ilham@umjambi.ac.id,${ }^{4}$ dimas@umjambi.ac.id
}

\begin{abstract}
Abstrak
Proses bisnis merupakan salah satu jenis kegiatan yang ada pada instansi yang dikelola untuk mencapai satu tujuan tertentu. Salah satu permasalahan dalam manajemen suatu instansi adalah tidak adanya Sistem Informasi yang mendukung manajemen dalam pelayanan, Permasalahan manajemen dalam hal ini adalah Klinik Basmalah Kota Jambi yaitu belum adanya sistem informasi yang mendukung manajemen dalam hal pelayanan, Secara umum untuk saat ini proses bisnis dalam hal pelayanan masi dikerjakan secara manual. Kondisi ini tentu di nilai kurang efektif dimana pengerjaan sangat bergantung dengan manusia.

Dari permasalahan tersebut salah satu tujuan penelitian ini adalah bagaimana menganalisis dan merancang sistem informasi E-Klink dengan menggunakan web, sehingga Klinik Basmallah dapat di akses oleh masyarakat dan pemangku kepentingan dengan memanfaatkan media Internet. Dengan sistem ini diharapkan dapat membantu manajemen Klinik Basmallah secara akurat. Sistem Informasi ini dirancang dapat bekerja selama 24 jam. Sesuai dengan kondisi pandemi covid-19 yang saat ini tengah mewabah.

Dalam penelitian akan diterapkan metode ekstraksi ciri berbasis statistis, berdasarkan metode statistis proses pada sistem sangat ditentukan oleh layanan yang ada pada klinik basmalah. Hasil dari pengaplikasian system informasi e-Klinik tersebut secara proses dapat membantu dan memudahkan user baik administrasi, pasien dan dokter hingga ke proses pelaporan serta ditambah dengan adanya layanan terintegrasi data pasien dengan system BPJS yang merupakan salah satu keunggulan system ini. Hasil pengujian yang telah dilakukan secara simulasi bersamaan menunjukkan rata-rata user akses eksekusi count tidak mencapai satu detik, authentication user ke active directory tidak berlangsung lama hanya 0,809 detik.
\end{abstract}

Kata kunci : Sistem, Informasi, Manajemen dan E-Klinik

\section{Pendahuluan}

Sistem merupakan salah satu bagian dari teknologi yang banyak dimanfaatkan oleh manusia di era digital saat ini, namun sistem tidak sebanding dengan kebutuhan manusia akan perkembangan teknologi, hal ini terlihat masih banyaknya proses yang masi manual, maka dari itu diperlukan sistem informasi yang baik terhadap suatu proses bisnis pada lembaga atau instansi. Sistem informasi yang banyak digunakan masih sebatas memenuhi peran teknologi yang digunakan untuk kepentingan tertentu. Fungsi lain dari Sistem ini adalah sebagai protector ketika user atau pemangku kepentingan membutuhkan informasi pada suatu Lembaga atau instansi. Pengaplikasian Sistem ini cenderung kurang efektif jika difungsikan untuk Sistem manajemen. Pada umumnya batasan Sistem yang dizinkan adalah Sistem yang memiliki kemampuan untuk mengurangi proses kerja dan dapat mepersingkat baik dalam hal waktu maupun kuantitas prosesnya sendiri. Dalam pemanfaatannya, Sistem ini dapat dimanfaatkan sebagai Sistem untuk membantu dalam proses dan juga sebagai pusat informasi, dalam hal ini studi kasus akan di aplikasikan di klinik basmalah kota jambi.

Beberapa penelitian terdahulu tentang sistem informasi kesehatan memang sudah pernah dilakukan sebelumnya. Diantaranya penelitian dengan judul Rancang Bangun Aplikasi Pendaftaran Online Jasa Pengobatan Berbasis Multimedia Pada Klinik Utama Siti Aksar Depok (Wardianto, 2019). Aplikasi pendaftaran online yang dibuat adalah pendaftaran antrian untuk layanan medis dokter gigi yang memberikan informasi nomor antrian dan perkiraan waktu kapan nomor antrian dilayani. Pada penelitian tersebut sistem yang dibuat berbasis desktop. perlu petugas pendaftaran atau admin menjalankan aplikasi.

Penelitian lainnya adalah Perancangan Sistem Pendaftaran Online Pasien Pada Klinik Dengan Metode First In First Out (FIFO) Berbasis Web Service (Abdullah \& Iswandi, 2015). Aplikasi yang 
dirancang ini berguna sebagai pendaftaran antrian untuk layanan medis dokter dan sarana menginformasikan tentang jasa yang ditawarkan oleh Kimia Farma Bireuen. Dalam perancangannya menggunakan metode FIFO yaitu dengan Singel Channel (satu pintu) ataupun multi channel (banyak pintu) tergantung pada kebutuhan dan dengan asumsi bahwa setiap pintu mempunyai tingkat pelayanan yang sama. Diharapkan dengan adanya sistem tersebut dapat memberi manfaat kepada masyarakat atau calon pasien yang akan berobat tidak harus datang langsung ke klinik untuk melakukan pendaftaran. Sistem Pendaftaran Online Pasien Pada Klinik Dengan Metode FIFO Berbasis Web Service ini, dapat menekan biaya pendataan pasien secara manual, sekaligus dapat mempromosikan berbagai informasi tentang pelayanan kesehatan di Klinik tersebut.

Beberapa penelitian terkait dengan Sistem informasi E-klinik banyak dikembangkan seperti: (a). Rancang Bangun Sistem Informasi Pelayanan Kesehatan Berbasis Web Pada Klinik Umum Galur Medika Jakarta Pusat, (Indarti, dkk, 2018), (b). Sistem informasi pendaftaran pasien pada klinik dr. Veri kajen kabupaten pekalongan Berbasis android. (Aslam Fatkhudin dkk, 2017). Pada umumnya Sistem yang telah dirancang hanya memberikan informasi saja sesuai dengan kondisi objek yang dipilih seperti Sistem informasi ruangan, informasi jadwal dokter yang dianggap tidak terlibat terhadap proses pelayanan atau Sistem yang tidak dimanfaatkan secara maksimal, hal ini tentu akan membatasi fungsi dari Sistem tersebut. Sementara secara terus menerus jumlah kebutuhan meningkat yang relatif banyak. Oleh karena itu, untuk memaksimalkan layanan Sistem informasi manajemen yang akan digunakan oleh klinik basmalah dengan skala pelayanan terpusat maka diperlukan suatu Sistem yang mempunyai fungsi lebih dari sekedar informasi, melainkan dapat membantu dalam beberapa proses diantaranya, layanan pendaftaran pasien secara online, layanan terintegrasi dengan Sistem BPJS Kesehatan, layanan diagnose penyakit dari dokter yang dapat di akses langsung oleh pasien dan tentunya layanan pusat informasi seputar Klinik Basmalah Kota Jambi.

Rata-rata klinik dan bahkan rumah sakit masih banyak menggunakan Sistem manual dikarenakan minimnya akses internet dan media informasi akan perkembangan teknolologi sangatlah susah untuk di jangkau, terlebih pada saat kondisi sekarang di masa pandemi covid-19, banyak sekali Lembaga atau instansi yang kehilangan karyawan akibat virus yang melanda negara kita ini.

Permasalahan dalam manajemen suatu lembaga dalam hal ini adalah Klinik Basmalah Kota Jambi yaitu tidak adanya sistem informasi yang mendukung proses bisnis manajemen dalam hal pelayanan. pada dasarnya pekerja di klinik melakukan pelayanan berdasarkan rutinitas jadwal yang telah ditentukan, tanpa memperhatikan kondisi dilapangan seperti cuaca yang tidak menentu, adanya pasien di luar jam kerja dan tingkat kebutuhan masyarakat dari luar daerah atau wilayah. Permasalahan ini dapat disimpulkan bahwa Klinik Basmalah tidak mempunyai system yang dapat membantu dalam menjalankan pelayanan dengan maksimal. Akibatnya terkadang masyarakat mengalami kendala untuk menjangkau Klinik baik dalam hal informasi maupun dalam hal proses pelayanan secara langsung.

Pada saat ini klinik Basmalah Kota Jambi secara umum masih manual dan tergolong sederhana, namun secara visi telah berani untuk membuka diri dalam hal perkembangan di semua unit yang ada utamnya dalam hal perkembangan dan pemanfaatan Sistem informasi yang berbasiskan teknologi. Dengan perkembangan Sistem informasi ini diharapkan dapat membantu semua unit dalam proses manajemen dalam memberikan layanan terbaiknya terhadap semua masyarakat. Dukungan teknologi informasi dapat mempermudah suatu pekerjaan karena tujuan dari Sistem Informasi Klinik sendiri dapat membantu mempermudah dalam memberikan pelayanan sehingga dapat menghemat waktu dan tenaga. Memperoleh hasil yang akurat, dengan adanya sistem informasi klinik maka rumah sakit bisa memperoleh data yang akurat dan tepat sesuai dengan kebutuhan rumah sakit. Mempercepat pelayanan, sehingga pelayanan yang diberikan bisa efektif dan efisien. (Umairo, murni. 10, 2019).

Sistem Informasi adalah suatu jaringan kerja dari prosedur-prosedur yang saling berhubungan, terkumpul bersama-sama untuk melakukan suatu kegiatan atau untuk tujuan tertentu. Selanjutnya menyatakan: "Sistem adalah suatu kumpulan atau himpunan dari unsur, komponen, atau variabel yang terorganisasi, saling berinteraksi, saling tergantung satu sama lain dan terpadu." Dari kedua uraian di atas menyatakan bahwa sistem informasi mempunyai elemen-elemen yang mempunyai suatu tujuan tertentu. Selain itu sistem informasi juga mempunyai karakteristik (Yakub. 2017).

Kenyataan Sistem yang dijalankan pada klinik basmalah kota jambi, cendrung tidak berjalan dengan baik. Oleh karenanya, penelitian bertujuan untuk merancang suatu Sistem informasi E-klinik sebagai penunjang proses manajemen pelayanan, dimana fungsinya dapat digunakan untuk membantu masyarakat dalam proses pelayanan pada Klinik Basmalah Kota Jambi sekaligus sebagai wujud peranan pembangunan daerah dalam hal pemanfaatan teknologi informasi yang telah di canangkan oleh pemrintah pusat, yang saat ini tengah berkembang pesat, baik dilingkungan kesehatan, Pendidikan, perdagangan, pertanian maupun di kalangan hiburan masyarakat. Dengan 
keberadaan Sistem ini diharapakan permasalahanpermasalahan yang timbul selama ini dapat terselesaikan dengan baik. Berikut gambaran skema proses sistem informasi e-klinik yang di tampilkan pada gambar 1 di bawah ini

Gambar skema proses sistem informasi

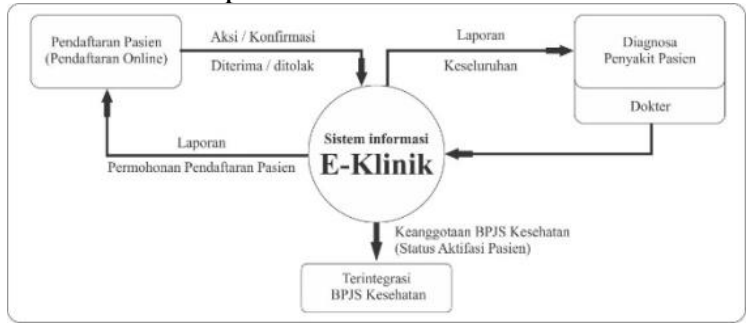

Gambar 1. Skema Proses Sistem Informasi E-Klinik.

\section{Tinjauan Pustaka}

\subsection{Kondisi Lingkungan}

Sistem Informasi E-Klinik adalah Sistem Informasi yang akan digunakan sebagai media penunjang proses manajemen dan layanan yang diberikan oleh klinik basmalah ke masyarakat. Sistem ini sangat membnatu dalam proses manajemen dan layanan yang ada di klinik basmalah kota jambi. Saat ini klinik basmalah tengah banyak menerima kunjungan dari masyarakat, baik yang ingin berkonsultasi maupun yang ingin berobat, secara keseluruhan proses manajemen yang ada masi di olah secara manual, kondisi ini telah berjalan lama dan masyarakat tetap antusias dikarenakan kurangnya pilihan lain yang lebih baik.

Melihat potensi lingkungan sekitar yang masih sangat jarang menggunakan Sistem informasi sebagai media komunikasi yang dapat menjawab solusi dari kondisi pandemi covid-19 yaitu mengurangi krumunan, menjaga jarak, serta dianjurkan untuk tetap di rumah jika tidak ada hal yang benar-benar penting. sebuah sistem informasi yang dapat bermanfaat dan mempunyai nilai jual yang lebih, bisa diterapkan guna menunjang permasalahan masyarakt di tengah pandemi Covid19. Sistem informasi ini disajikan dengan berbagai macam proses layanan yang dapat di akses langsung oleh masyarakat, seperti layanan Pendaftaran online, layanan informasi langsung ke Sistem BPJS kesehatan, Layanan diagnose dari dokter langsung, layanan informasi pasien yang ada di klinik dan layanan proses manajemen yang terintegrasi oleh semua unit yang ada sebagai salah satu keunggulan klinik dan sebagai ciri khas yang nantinya di miliki oleh klinik basmalah Kota Jambi. Dengan ini saya mengharapkan dapat mengaplikasikan Sistem informasi E-Klinik ini dengan baik dan benar-benar bermanfaat untuk warga sekitar lingkungan Klinik Basmalah dan Bahkan Masyrakat luas yang ada di Kota Jambi dan Provinsi Jambi pada Umumnya.
Dari segi penunjang seperti layanan koneksi internet telah tersedia dengan kwalitas sangat baik, selain itu untuk akses masyarakat dengan menggunakan media smart phone telah dapat mengakses dengan mudah, karan telah dipastikan penggunaan jaringan propaider semua sudah dapat digunakan, semua telah menggunakan jaringan $4 \mathrm{G}$

\subsection{Perkembangan Sistem}

Sistem Informasi Klinik (E-Klinik) adalah teknologi informasi yang telah terintegrasi dengan aplikasi Primary Care. Aplikasi tersebut yang dipersiapkan untuk memastikan proses pelayanan jaminan kesehatan berjalan sesuai prosedur yang ditetapkan. Dengan menggunakan E-Klinik ini operasional klinik akan menjadi lebih efektif karena fungsi 2 aplikasi yang berbeda bisa dijalankan dengan hanya menggunakan E-Klinik. Proses integrasi ketiga aplikasi tersebut digambarkan melalui diagram di bawah ini, sebagai mana yang telah ditampilkan pada gambar 2 berikut;

Gambaran diagram integrasi e-klinik

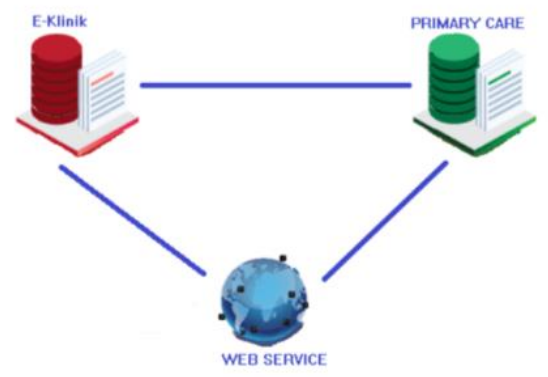

Gambar 2. Diagram Integrasi E-Klinik

Implementasi E-Klinik yang akan diintegrasikan dengan Primary Care memberikan berbagai manfaat dan fitur bagi klinik seperti yang tertera di bawah ini:

\section{a. Meningkatkan efisiensi operasional klinik}

BPJS Kesehatan menggunakan aplikasi primary care untuk memverifikasi keanggotaan dan mengklaim kunjungan. Jika klinik sudah menggunakan E-klinik, ini berarti akan ada dua aplikasi berbeda yang digunakan untuk memproses setiap pasien BPJS. Proses verifikasi keanggotan BPJS di E-Klinik saat melakukan pendaftaran dapat dilihat melalui gambar 3 berikut:

Halaman Verifikasi Keanggotaan pasien BPJS

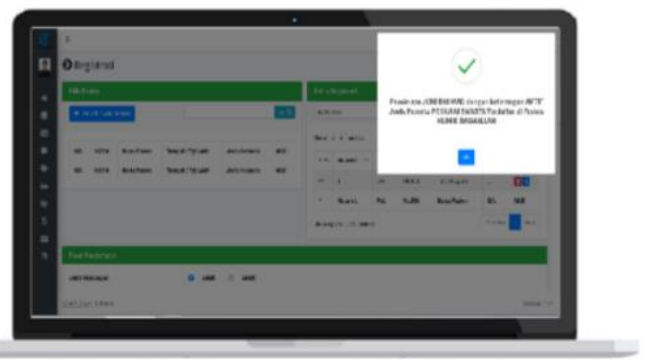


Gambar 3. Verifikasi Keanggotaan pasien BPJS di E-Klinik saat pendaftaran

\section{b. Meningkatkan Akurasi}

Melalui integrasi E-Klinik dengan Pcare, proses verifikasi keanggotaan BPJS dan pelayanan pasien dapat dilakukan dalam satu layar pendaftaran tanpa harus mengakses aplikasi Pcare. Selain mengurangi proses perekaman data yang repetitif, hal ini juga mengurangi kemungkinan kesalahan input data ke dua aplikasi yang berbeda, yaitu E-Klinik dan Pcare. Hal ini juga membantu menjaga konsistensi data dalam dua aplikasi tersebut.

\section{Metode Penelitian}

Untuk merancang Sistem informasi E-Klinik, berikut tahapan perancangan yang dilakukan sebagaimana tergambar pada Gambar 4 di bawah ini;

Gambaran tahapan proses penelitian

\begin{tabular}{|c|}
\hline $\begin{array}{l}\text { Rumusan Spesisifikasi Sistem: } \\
\text { 1. Batasan proses manajemen } \\
\text { 2. Sumber daya layanan } \\
\text { 3. Human interface }\end{array}$ \\
\hline$\downarrow$ \\
\hline $\begin{array}{l}\text { Tahap Perancangan: } \\
\text { 1. Alur Proses Sistem } \\
\text { 2. Data Base } \\
\text { 3. Hak akses \& Administrator }\end{array}$ \\
\hline$\downarrow$ \\
\hline $\begin{array}{l}\text { Tahap Pengujian Sistem: } \\
\text { 1. Perangkat Lunak } \\
\text { 2. Sistem proteksi hubungan singkat }\end{array}$ \\
\hline$\downarrow$ \\
\hline $\begin{array}{l}\text { Laporan Kinerja Sistem } \\
\text { 1. Spesifikasi Sistem } \\
\text { 2. Kurva karakteristik dari Sistem } \\
\text { 3. Cara instalasi atau pemasangan Sistem }\end{array}$ \\
\hline
\end{tabular}

Gambar 4. Tahapan Proses Pelaksanan Kegiatan

Sebagai panduan awal dalam penelitian ini, maka akan dilakukan Studi Literatur. Studi ini dilakukan untuk mencari data-data, jurnal, buku, artikel dan referensi lain yang berhubungan dengan sistem informasi E-Klinik dan Aplikasi lain yang berhubungan dengan Sistem Informasi, serta beberapa alternative-alternative yang telah ditawarkan peneliti sebelumnya dalam hal merancang sistem informasi.

Berikut penjelasan dan pemaparan dari tahapan rencana kegiatan yang akan dilakukan oleh penulis seperti yang telah digambarkan diatas:
1. Rumusan spesifikasi sistem

dalam hal ini akan penulis akan berkoordinasi langsung dengan unit-unit terkait berkenaan dengan proses manajemen dan juga sumber daya yang ada.

\section{Perancangan sistem}

Pada tahap rancangan sistem penulis membuat alur proses tekait dengan sistem yang akan di bangun yang kemudian disesuaikan dengan rancangan data base yang akan digunakan serta memperhitungkan hak akses apa saja yang akan diberikan pada sistem tersebut. Membuat pemodelan kebutuhan Sistem Informasi dengan menggambarkan fungsi-fungsi pengelolaan manajemen

\section{Pengujian sistem}

Pada tahap ini penulis melakukan pengujian sistem secara sederhana yang berhubungan dengan proses bisnis yang ada baik berupa kesiapan software maupun dari kesiapan hardwarenya sendiri, akan tetapi pada tahap ini pengujian hanya dilakukan secara simulasi sederhana dengan tujuan sistem telah benar-benar siap untuk digunakan dan diaplikasikan.

\section{Pembuatan Laporan}

Dalam tahap pembuatan laporan adalah merupakan tahapan terakhir dalam proses penelitian yang akan dilakukan, dimana setiap proses penelitian yang telah dilakukan akan di rekam dan didokumentasikan dalam bentuk tulisan sehingga penelitian ini benar-benar dapat terselesaikan dengan baik.

\section{Hasil dan Pembahasan}

\subsection{Perancangan Desain Sistem}

a. Sistem Informasi E-Klinik pada bagian menu login, dapat dilihat pada gambar 5 di bawah ini;

Tampilan rancangan halaman Login

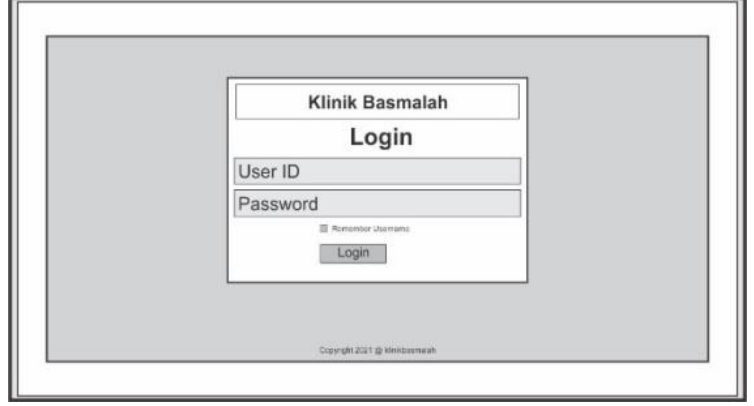

Gambar 5. Rancangan login E-klinik

b. Desain Sistem Informasi E-klinik pada bagian menu Home, juga dapat di lihat pada gambar 6 berikut ini;

Tampilan rancangan halaman home 


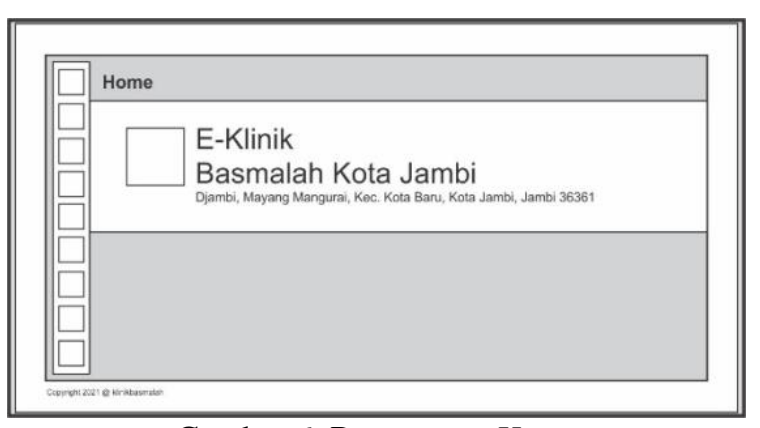

Gambar 6. Rancangan Home

Sistem dipasang untuk menggantikan beberapa proses kerja yang biasanya dikerjakan secara manual, dimana batasan dari layanan yang ada di klinik dapat di atur menggunakan Sistem informasi. Batasan Sistem yang akan digunakan secara fleksibel dapat ditentukan sesuai kebutuhan selain itu, Sistem ini dapat digunakan sebagai monitoring layanan dan Proses manajemen dari klinik Basmalah Kota Jambi, hal ini dapat terjadi dikarenakan Sistem ini dirancang dengan Sistem online dengan kata lain terkoneksi langsung oleh internet.

c. Hasil Pengujian Sistem

Pada tahap ini akan dilakukan pengujian sistem yang bertujuan untuk menemukan kesalahankesalahan atau kekurangan-kekurangan pada perangkat lunak yang diuji. Pengujian bermaksud untuk mengetahui perangkat lunak yang dibuat sudah memenuhi kriteria yang sesuai dengan tujuan perancangan perangkat lunak tersebut. Pengujian perangkat lunak ini menggunakan pengujian black box. Pengujian black box berfokus pada persyaratan fungsional perangkat lunak tanpa menguji desain dan program. Untuk lebih jelas skenario pengujian dapat dilihat pada table 1 dan 2 berikut ini;

Tabel 1. Skenario Pengujian Sistem Admin

\begin{tabular}{lll}
\hline \multicolumn{1}{c}{ Uji Fitur } & Detail Pengujian & $\begin{array}{c}\text { Jenis } \\
\text { Pengujian }\end{array}$ \\
\hline Login & Isi form login & Black box \\
\hline $\begin{array}{l}\text { Form } \\
\text { Pendaftaran }\end{array}$ & $\begin{array}{l}\text { Menambah data } \\
\text { pendaftaran }\end{array}$ & Black box \\
\hline Form User & $\begin{array}{l}\text { Menambah data } \\
\text { user }\end{array}$ & Black box \\
\hline Daftar & $\begin{array}{l}\text { Menampilkan data } \\
\text { pendaftar }\end{array}$ & Black box \\
\hline Profil Klinik & $\begin{array}{l}\text { Mengelola data } \\
\text { profil }\end{array}$ & Black box \\
& & \\
\hline
\end{tabular}

Tabel 2. Skenario Pengujian Sistem User

\begin{tabular}{lll}
\hline Uji Fitur & Detail Pengujian & $\begin{array}{c}\text { Jenis } \\
\text { Pengujian }\end{array}$ \\
\hline Registrasi & Isi form login & Black box \\
\hline $\begin{array}{l}\text { Form } \\
\text { Pendaftaran }\end{array}$ & $\begin{array}{l}\text { Menambah data } \\
\text { pendaftaran }\end{array}$ & Black box \\
\hline Form Pesan & Mengirim Pesan & Black box \\
\hline Profil User & $\begin{array}{l}\text { Mengelola data } \\
\text { profil }\end{array}$ & Black box \\
\hline
\end{tabular}

Sistem Informasi E-Klinik sebagaimana ditunjukkan pada Gambar di bawah ini. Sistem terdiri dari menu login, Home, Menu Navigasi, Pendaftaran, Registrasi, Kasir, Kas Klinik, Farmasi, Hutang dan Piutang. System di rancang semudah mungkin untuk dapat di pahami pengguna atau user serta dapat di akses dimana saja. System dapat terkoneksi dengan beberapa user yang terkait ke beberapa unit pelaksana pelayanan.

Untuk memanfaatkan system sebagai pusat layanan perlu adanya proses instalasi program yang di susun sebelumnya untuk menunjang dari pada kerja system tersebut dengan bahasa pemerograman web. system monitoring yang di pilih pada system ini adalah system informasi e-klinik pada Klinik Basmalah Kota Jambi, hal ini dikarenakan klinik ini masi menggunakan layanan secara manual di lain sisi klinik adalah layanan kesehatan yang perannannya sangat penting dalam hal kesehatan utamanya di tengah pandemi covid-19 saat ini. Dan klinik tersebut belum ada tersentuh oleh teknologi baik dalam hal proses pengolahan maupun dalam hal proses layanannya sendiri. dengan demikian kami menilai ini sangat baik dilakukan penelitian dimana kedepannya benar-benar dapat diterapkan sehingga dapat memberikan manfaat yang baik kepada masyarakat, baik dalam hal efisiensi waktu maupun dalam hal peningkatan kwalitas layanan.

\subsection{Hasil}

Berikut ini hasil pengujian yang digambarkan dalam bentuk proses system informasi E-Klinik Basmalah Kota Jambi.

1. Login E-Klinik

Masukan user name dan password kemudian klik login, perhatikan gambar 7 di bawah ini;

\section{Tampian Halaman login}

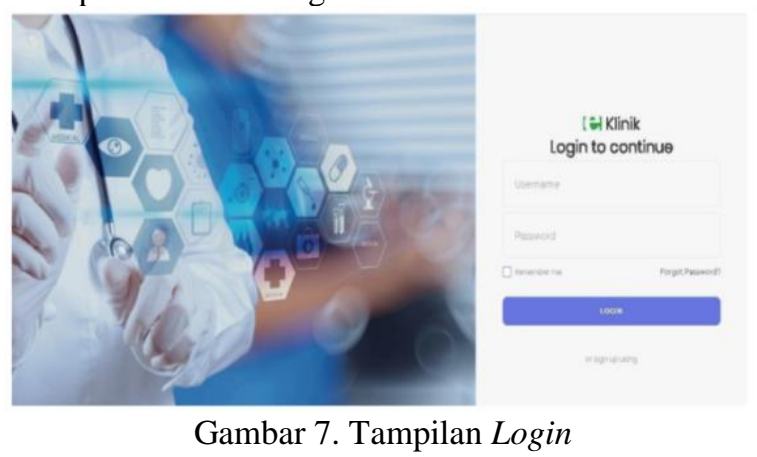

\section{Home}

Menu Home berisi informasi nama klinik alamat dan nomor telephone, juga dapat di lihat pada gambar 8 di bawah ini;

Tampilan halaman home 


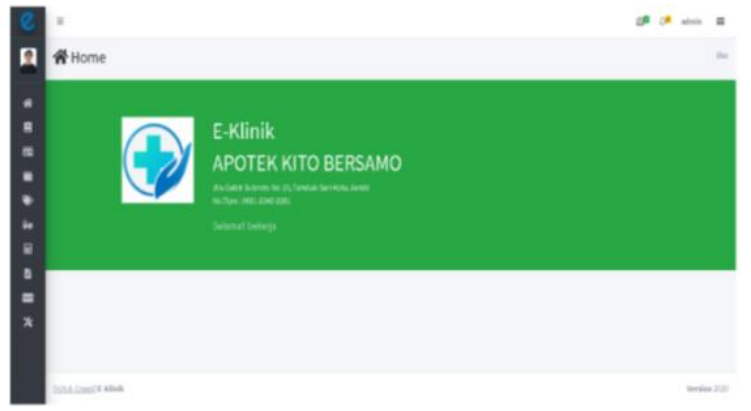

Gambar 8. Tampilan Menu Home

Laporan Kunjungan Klinik Berisi daftar pasien yang berobat pada tanggal yang di pilih terdapat fitur untuk cetak laporan kunjungan, seperti terlihat pada gambar 9 di bawah ini;

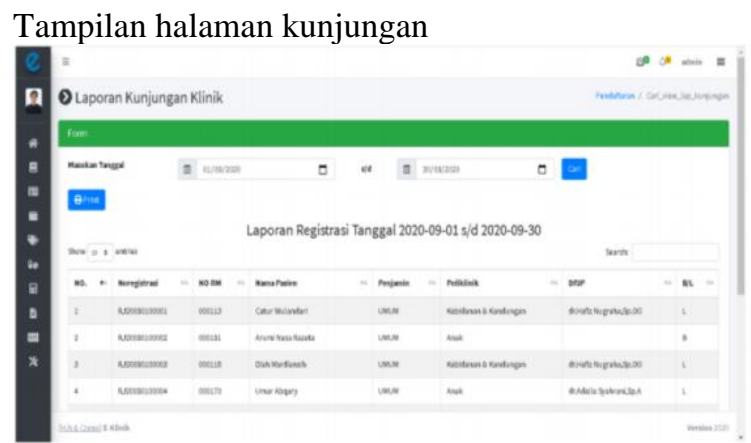

Gambar 9. Tampilan Laporan Kunjungan Klinik

\section{Layanan sistem}

Sebagai layanan system yang baik, berikut dapat membantu dan memudahkan user baik administrasi, pasien dan dokter hingga ke proses pelaporan a. Dokter

Beriisi data nama-nama dokter yang praktek di klinik terdapat beberapa menu pendukung diantaranya tambah, edit, hapus dan cetak laporan daftar nama dokter, sesuai yang terlihat pada gambar 10 berikut;

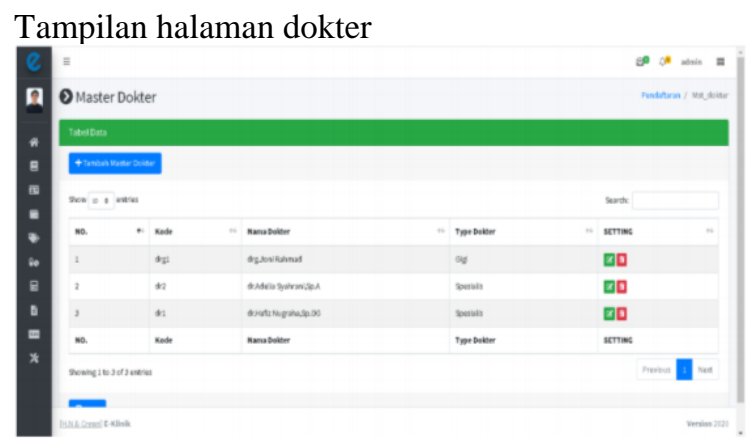

Gambar 10. Tampilan menu dokter

\section{b. Pasien}

Beriisi data nama-nama pasien yang berobat di klinik terdapat beberapa menu pendukung diantaranya tambah dan edit, perhatikan gambar 11 berikut;

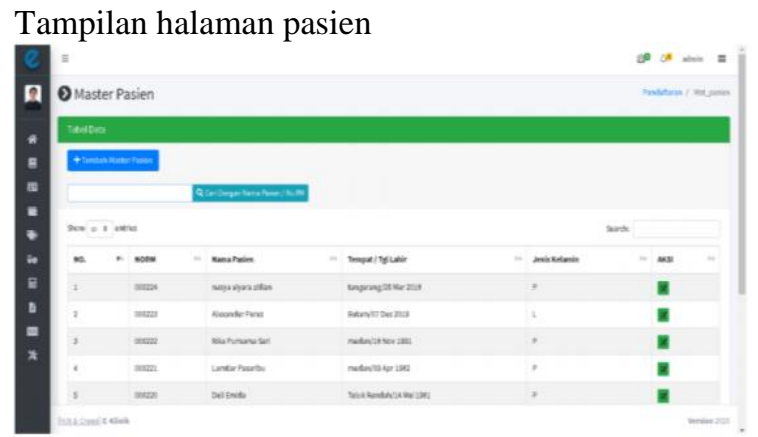

Gambar 11. Tampilan menu pasien

\section{c. Registrasi}

Tata cara pendaftaran pasien rawat jalan, tanda warna merah untuk mencari nama pasien lama berdasarkan nama pasien dan no rekam medis, sebagaimana ditampilkan pada gambar 12 dan 13 berikut;

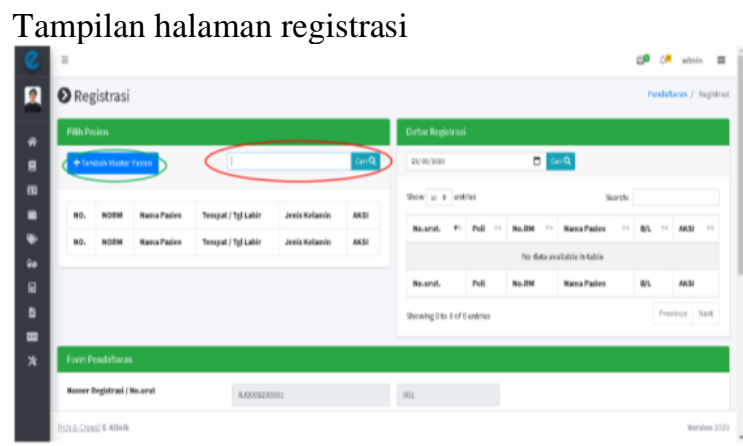

Gambar 12. Tampilan menu registrasi

Tanda warna hijau untuk menambah pasien baru
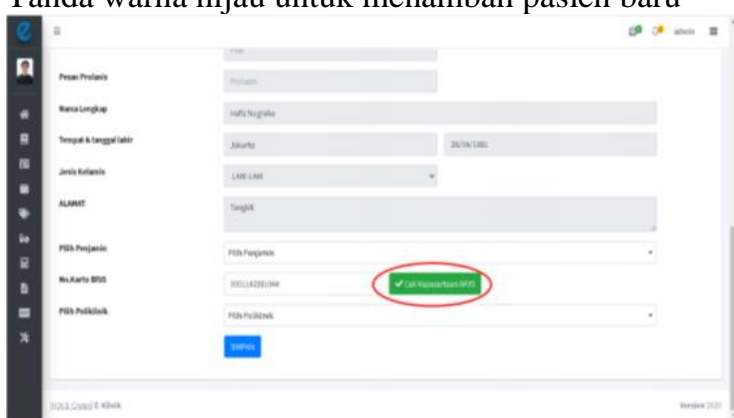

Gambar 13. Tampilan menu menambah pasien

Keterangan:

1. Pilih penjamin untuk pendaftaran rawat jalan

2. Pilih Poliklinik

3. Klik simpan untuk menyimpan data pendaftaran

4. Klik Cek Kepesertaan BPJS untuk pasien dengan penjamin BPJS untuk melihat keaktifan kepesertaan BPJS

Terlihat pada gambar bahwa peserta masih aktif sebagai peserta BPJS, lihat gambar 14 berikut;

Tampilan halaman informasi BPJS 


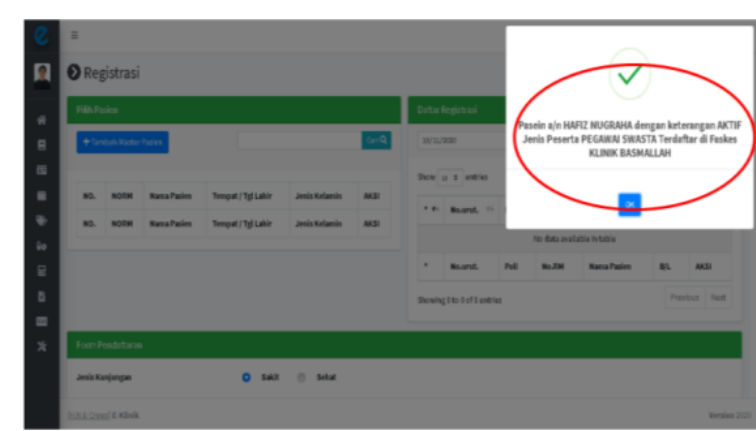

Gambar 14. Tampilan Informasi BPJS

Untuk memudahkan dalam proses pelaporan system ini juga telah dilengkapi dengan menu cetak laporan sebagaimana yang ditampilkan pada gambar 15 berikut;

Tampilan halaman cetak laporan

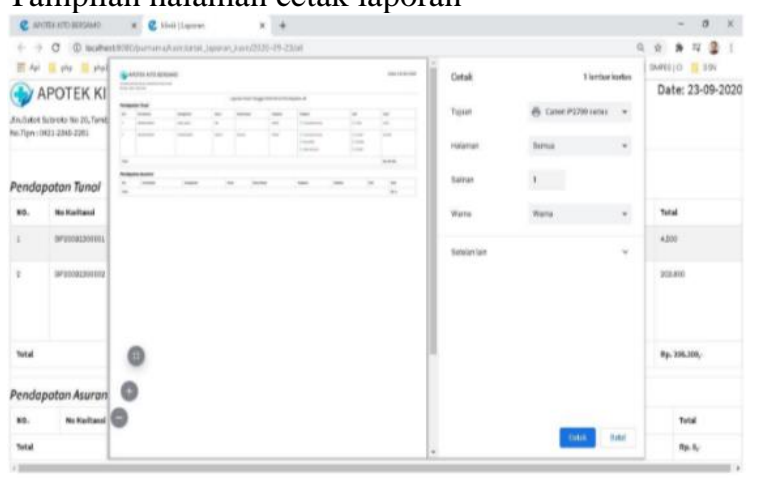

Gambar 15. Tampilan Cetak Laporan

\subsection{Pengujian}

Sebelum membahas hasil pengujian, perlu adanya penjabaran secara detail scenario pengujian simulasi web service yang dilakukan. Pengujian dilakukan pada aplikasi web pendukung metodemetode ROA (GET, POST, PUT, DELETE). Aplikasi mengirim sebuah perintah yang akan dieksekusi oleh web service berupa logic-logic string untuk disampaikan kepada database. Tool yang digunakan dalam pengujian ini adalah Activity Monitoring dari MS SQL Management Studio untuk mengukur antrian eksekusi perintah yang diminta oleh aplikasi web per user akses. Pengujian dilakukan secara bersamaan untuk mengetahui antrian eksekusi pada database. Setiap client mengakses aplikasi web tersebut, pada sisi server dilakukan monitoring eksekusi perintah dari klien. Setiap klien akan dicatat dalam melakukan eksekusi yang ditunjukkan dengan tampilan grafik, jika web service mengeksekusi perintah tidak membutuhkan waktu lama (timeout) atau melakukan query yang membutuhkan cost performace yang tinggi (expensive query) maka pencatatatan pada moinitoring akan mencatat dengan kondisi penimpaan (replace) dan jika terjadi antrian lama, membutuhkan waktu lama (timeout) serta membutuhkan cost performance tinggi (expensive query) maka proses tersebut akan di kill proses hingga tidak menyebabkan terjadinya down pada sisi server

Waktu eksekusi yang diuji oleh perintah (query) mendapatkan hasil eksekusi count setiap ms (milli second) per computer sesuai dengan data yang ada pada tabel 3 dibawah ini:

Tabel 3. Hasil Pengujian Komputer

\begin{tabular}{ccc}
\hline No & Komputer Tes & Nilai \\
\hline 1 & Komputer 1 & 0.805 \\
\hline 2 & Komputer 2 & 0.804 \\
\hline 3 & Komputer 3 & 0.802 \\
\hline 4 & Komputer 4 & 0.805 \\
\hline 5 & Komputer 5 & 0.809 \\
\hline
\end{tabular}

Proses eksekusi perintah menunjukkan rata-rata user akses eksekusi count jika dihitung tidak mencapai satu detik yang menunjukkan data eksekusi normal ketika proses login user ke database yang menampilkan proses pemanggilan data yang berjalan berupa authentication user ke active directory tidak berlangsung lama, hasil tabel diatas berupa grafik dapat dilihat pada gambar 11 Grafik eksekusi count dibawah ini;

Tampilan Garfik hasil pengujian

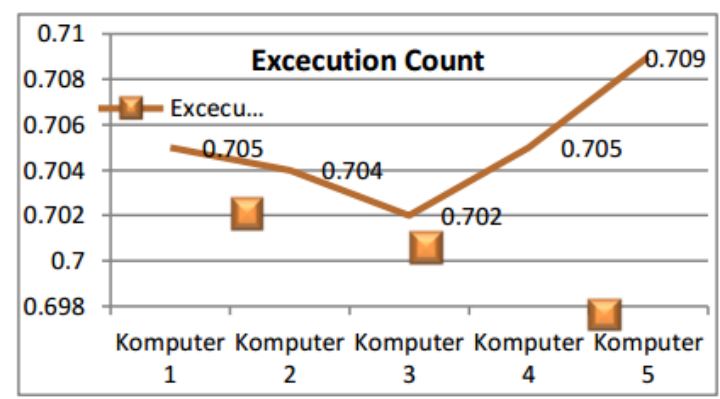

Gambar 16. Grafik hasil pengujian

\section{E-RM}

1. Asesmen dokter: mengisi formulir asesmen rekam medis dokter Permintaan dan Isi hasil penunjang

2. Permintaan farmasi: dokter membuat permintaan obat / resep ke apotek

3. Input Tindakan: dokter mengimput billing tindakan poliklinik yang terjadi selama rawat jalan berlangsung

4. Tambah Catatan Obat Kronis: dokter membuat catatan obat kronis

5. Isi Surat Rujukan Balik: dokter mengisi surat rujuk balik dari rumah sakit

6. Isi penunjang medis: dokter mengisi nilai hasil labor untuk dikirik ke BPJS secara bridging

7. Penggunaan obat bpjs: dokter mengisi daftar pemakaian obat untuk dikirik ke BPJS secara bridging

8. Tambah catatan hasil laboratorium: dokter membuat catatan untuk hasil laboratorium 
9. Tambah catatan hasil Radiologi: dokter membuat catatan untuk hasil Radiologi

Riwayat Pasien

1. Kiup Pasien: berisi data histori rekam medis

2. Kiup Pasien BPJS: berisi data histori pelayanan kesehatan dengan penjamin BPJS

3. Transaksi: berisi data histori transaksi

4. Pemakaian Obat: berisi data pemakaian obat yang telah diresep oleh dokter

5. Catatan Obat Kronis: berisi data catatan obat kronis oleh dokter

6. Hasil Penunjang Medis: berisi data catatan penunjang medis lab dan radiologi dll yang telah di kirim ke data BPJS

7. Pemakaian Obat BPJS: berisi data catatan pelaporan pemakaian obat ke BPJS

8. Catatan Surat Rujuk Balik: berisi riwayat data catatan surat rujuk balik

9. Catatan Hasil Labor: berisi data histori catatan labor Catatan Hasil Radiologi

\section{Kesimpulan dan Saran}

Berdasarkan perancangan dan pengujian sistem informasi e-Klinik pada Klinik Basmalah Kota Jambi dapat disimpulkan, yaitu Sistem Informasi eKlinik yang dirancang menggunakan aplikasi berbasis Website yang didukung oleh jaringan internet untuk memudahkan user dalam pengaksesan sistem selama 24 jam. Hasil dari pengaplikasian system informasi e-Klinik tersebut secara proses dapat membantu dan memudahkan user baik administrasi, pasien dan dokter hingga ke proses pelaporan, selain itu sistem ini juga memiliki keunggulan yaitu dengan sistem ini telah dilenkapi dengan keterintegrasian dengan sistem BPJS dengan hasil sukses mengecek kepesertaan pasien pada sistem BPJS kesehatan. Secara langsung pasien dapat mengetahui tentang informasi kepesertaan BPJS nya. Dalam hal proses eksekusi perintah, menunjukkan rata-rata user akses eksekusi count jika dihitung tidak mencapai satu detik yang menunjukkan data eksekusi normal ketika proses login user ke database yang menampilkan proses pemanggilan data yang berjalan berupa authentication user ke active directory tidak berlangsung lama yaitu di angka 0,809 detik. selanjutnya penelitian ini akan dipublikasikan sebagai bentuk keseriusan dalam melakukan penelitian ini.

Adapun saran yang dapat diberikan adalah hendaknya bagian administrasi terlebih dahulu mendapatkan pelatihan, agar aplikasi ini dapat berfungsi secara maksimal selain itu juga agar sistem yang di bangun ini dapat di buat lebih kompleks lagi untuk memaksimalkan pelayanan yang ada pada Klinik Basmalah tersebut. Dengan melibatkan semua unit terkait mulai dari level pimpinan (sebagai pemangku kebijakan) hingga ke bagian palayanan yang bersentuhan langsung dengan konsumen atau masyarakat.

\section{Daftar Pustaka:}

Anamisa, y. k. (2016). Pemrograman Basis Data Berbasis Web Menggunakan PHP \& $M y S Q L$. Yogyakarta: Graha Ilmu.

Anggun Sri, S. K. (2015). Sistem Informasi Klinik Bhakti . e-Proceeding of Applied Science: Vol.1, No.3 Desember 2015, 1921.

Aslam. F, D. N. (2017). sistem informasi pendaftaran pasien pada klinik dr. veri kajen kabupaten pekalongan berbasis android. Jurnal Ilmiah Edutic, 51-58.

Dahlan Abdullah, I. (2015). PERANCANGAN SISTEM PENDAFTARAN ONLINE PASIEN PADA KLINIK DENGAN METODE FIFOBERBASIS WEB SERVICE. Techsi Vol. 6 No.1, 103 - 115.

Diah Wijayanti Sutha, S. M. (2018). ADMINISTRASI PERKANTORAN Cara Mudah Memahami Konsep Dasar Administrasi Perkantoran Secara Umum. Sidoarjo: Indomedia Pustaka.

Faza Muhammad Raihan. (2021). PERANCANGAN SISTEM INFORMASI REKAM MEDIS PADA KLINIK SAFFIRA SENTRA MEDIKA BATAM. Jurnal SNATi. Volume 1. Nomor 1, 47-56.

Irvani, E. Y. (2017). Pengantar Sistem Informasi. Yogyakarta: Andi Offset.

Juairiyah, B. O. (2017). Dalam Administrasi Perkantoran (Studi Kasus: Balitbangda Prov. Sumsel). Jurnal Pembangunan Nagari, 75-84.

Khairuldi, M. d. (2020). Perancangan Sistem Informasi Administrasi Data Kependudukan Desa Sumber Jaya, Kec. Kumpeh Ulu, Kab. Muaro Jambi. Processor, 62-74.

Laraswati, I. d. (2018). Rancang Bangun Sistem Informasi Pelayanan Kesehatan Berbasis Web Pada Klinik Umum Galur Medika Jakarta Pusat. Jurnal Teknik Komputer AMIK BSI, 71-76.

Mahendra, M. d. (2017). SISTEM INFORMASI KLINIK BERBASIS WEB PADA KLINIK UMUM DAN KECANTIKAN DOKTER GALUH DWI ANANDHITA JAKARTA. CKI On SPOT, 1-16.

Prof. Dr. Sri Mulyani, N. A. (2016). Analisis dan Perancangan Sistem Informasi Manajemen Keuangan Daerah: Notasi Pemodelan Unified Modeling Language. Bandung: ABDI SITEMATIKA.

Rasyid, A. H. (April 2016). SISTEM INFORMASI MONITORING PENGEMBANGAN SOFTWARE PADA TAHAP 
DEVELOPMENT BERBASIS WEB. Jurnal Informatika Vol.III No.1, 41-50.

Rosa Ariani Sukamto, M. S. (2018). REKAYASA Perangkat Lunak: Terstruktur dan Berorientasi Objek. BANDUNG: Informatika.

Saleh Yaakub, J. (2017). ANALISIS PEMODELAN SISTEM INFORMASI MANAJEMEN ASET BERBASIS WEB PADA POLITEKNIK JAMBI. Jurnal Manajemen Sistem Informasi Vol 2 No 3, 610-628.
Wardianto, M. (2019). Rancang bangun aplikasi pendapatan online jasa pengobatan berbasis multimedia pada Klinik Utama Siti Aksar Depok. Depok: UIN Syarif Hidayatullah Jakarta : Fakultas Sains dan Teknologi UIN Syarif Hidayatullah.

Yakub. (2017). Pengantar Sistem Informasi. Yogyakarta: raha Ilmu. 
Volume 8, Edisi 2, Februari 2022

$18 \mid \mathrm{H}$ a 1 a $\mathrm{m}$ a n 